\title{
Application of Problem-Based Learning to Enhance Students Learning Outcomes in Basic Competencies of Maintaining Brake Systems
}

\author{
Cristian E. Reinsini* I Wayan Susila, \& Mochammad Cholik \\ Department of Technology and Vocational Education, Postgraduate of State University of Surabaya, Surabaya, 60213, \\ Indonesia. \\ kezia.19005@mhs.unesa.ac.id \\ cristianreinsini16070895029@mhs.unesa.ac.id; wayansusila@unesa.ac.id; mochcholik@unesa.ac.id \\ *Corresponding Author: cristianreinsini16070895029@mhs.unesa.ac.id | Phone Number: +6285338355415
}

\begin{abstract}
The purpose of this study was to determine the effect of the application of problem-based learning to improve student learning outcomes in the subject of Basic Competencies for Maintaining Brake Systems at SMK Negeri 2 Kupang. This study used a $2 \times 2$ factorial research design with experimental methods with a quantitative approach, consisting of two classes: the experimental and control classes. The control class is taught using a direct learning model, and the experimental class is taught using a problem-based learning model. The research sample was 70 students, 36 students from TKR 2 class (experiment class), and 34 students from class XI TKR 3 (control class). The instrument used consisted of a questionnaire of analytical skills, a test of learning outcomes in the cognitive domain, affective domain, and psychomotor domain. This study's results indicate that (1) student learning outcomes using problem-based learning models are significantly higher than learning outcomes for students who use the direct learning model; (2) the learning outcomes of students who have high analytical skills are significantly higher than the learning outcomes of students who have low analytical skills; and (3) there is an interaction between the use of problem-based learning models and direct learning models on learning outcomes in the basic competency subject of the brake system at SMKN 2 Kupang.
\end{abstract}

Keywords: problem-based learning; teaching materials; learning outcomes; mantaining brake systems

\section{Introduction}

Education is the most fundamental part of realizing quality human resources. Therefore, national education is expected to form students or young people who have good character and dignity to learn quality Indonesian education. Desty (2012) states that schools must foster, develop, and perfect students' potential and their life and future as one of the educational institutions for learning. As an educator, the teacher is the creator of learning conditions for students that are designed deliberately, systematically, and continuously. A fair learning process requires a process of interaction between all parties, both from teachers with students or students with students. Simultaneously, the success of a lesson is seen from students' learning outcomes during the learning process. The problem-based learning model is an innovative learning model that can provide active learning conditions for students (student-centered) and also uses problems as a first step in gathering and integrating new knowledge to students. According to Ward \& Peppard (2002), the problembased learning model involves students solving a problem through the stages of the scientific method so that students can learn knowledge related to the problem and, at the same time, have the skills to solve problems.

Widiada, Candiasa, \& Natajaya (2013) states that the information received by students will be long remembered if students learn through problem-solving by problems experienced in everyday life. Setyosari (2010) states that problem-based learning is a learning model characterized by real issues as a context for students to learn critical and problem-solving skills and gain knowledge. But in general, some teachers in their learning are still limited to verbal reasoning and logical thinking. Meanwhile, high-level thought processes, including analytical skills, are rarely trained and formed (Susanto, 2012; Wahyuni et al, 2020; Siregar et al, 2020). Several previous studies, such as that conducted by Kharismaputra et al (2020); Aprilianu et al (2020); Mostofa et al (2019); Puspitasari et al (2020); Widianto et al (2020); and Dewi (2019) that students' abilities are influenced by the learning model used by the teacher, one of which is a problem based learning model that provides activeness to students through various problem models provided by the teacher, so that 
in the end students will form higher-order thinking skills.

Based on the results of interviews with the teacher of Light Vehicle Engineering Study Programs at SMKN 2 Kupang, it was found that students in class XI TKR had low scores and difficulty learning the competencies of maintaining brake systems. It's indicated by the scores of students who do not meet the minimum completeness criteria (KKM), wherein class XI TKR 1 Academic Year 2019/2020, and there are only 12 students who reach the minimum completeness criteria out of a total of 33 students. While, in class XI TKR 2, only 14 students reached the minimum completeness criteria out of 31 students. This condition occurs because teachers still use the conventional learning model or direct learning model to deliver learning materials. Besides, direct learning can only be applied to specific fields of study with a step-by-step teaching system. The direct learning model also relies heavily on teacher reflection so that students have little opportunity to be actively involved during teaching and learning activities.

Efforts that can improve student learning outcomes are applying new, better, and more appropriate learning models; one of them is a problem-based learning model. So, through the problem-based learning model, it is expected that the analytical skills and student learning outcomes can be increased by giving problems in each learning process. The study Anazifa (2016) show that problem-based learning affects critical thinking and student learning outcomes, especially in their cognitive aspects, because it gives students opportunities to participate during the learning process actively.

Based on the background that has been described, then the aims of this study is to (1) analyze the differences in learning outcomes for students who learn using problem-based learning models than those who learn using direct learning models; (2) analyze the differences in learning outcomes for students with a high level of analytical ability than students with a low level of analytical skills; (3) analyze the interaction between learning models and analytical skills on learning outcomes on the brake system's basic competency.

\section{Materials and Methods}

This study's subjects were students of class XI Light Vehicle Engineering at SMKN 2 Kupang, that divided into two groups, consisting of 36 students from XI TKR 2 class (experiment class) was taught using a problem-based learning model, and 34 students from class XI TKR 3 (control class) was conducted using the direct learning model. This type of research is experimental research with a quantitative approach. The research was conducted to obtain a real picture of student learning outcomes in terms of problem-solving analysis skills in the basic competency of brake systems that apply problem-based learning models and direct learning. The instrument used consisted of a questionnaire of analytical skills, a test of learning outcomes in the cognitive domain, affective domain, and psychomotor domain. At the same time, the research design used in this study was a 2x2 factorial design (Sugiyono, 2013). Meanwhile, the statistical hypothesis test used 2-way ANCOVA to analyze significance in different levels of treatment with a probability of $5 \%$.

Table 1. Factorial Design Research $2 \times 2$ (Sugiyono, 2013)

\begin{tabular}{cccc}
\hline CLASS & TEST & TREATMENT & TEST \\
\hline $\mathrm{E}$ & $\mathrm{O}_{1}$ & $\mathrm{X}_{1} \mathrm{Y}_{1}$ & $\mathrm{O}_{3}$ \\
& & $\mathrm{X}_{1} \mathrm{Y}_{2}$ & $\mathrm{O}_{4}$ \\
$\mathrm{~K}$ & $\mathrm{O}_{2}$ & $\mathrm{X}_{2} \mathrm{Y}_{1}$ & $\mathrm{O}_{5}$ \\
& & $\mathrm{X}_{2} \mathrm{Y}_{2}$ & $\mathrm{O}_{6}$ \\
\hline
\end{tabular}

Information:

$\begin{array}{ll}\mathrm{E} & =\text { Experimental class } \\ \mathrm{K} & =\text { Control class } \\ \mathrm{O} 1,2 & =\text { Pre-test } \\ \mathrm{O} 3,4,5,6 & =\text { Post-test } \\ \mathrm{X} 1 & =\text { Treatment in the experimental class (taught by problem-based learning) } \\ \mathrm{X} 2 & =\text { Treatment in the control class (taught by direct learning) } \\ \mathrm{Y} 1 & =\text { High level of analytical skills } \\ \mathrm{Y} 2 & =\text { Low level of analytical skills }\end{array}$




\section{Results and Discussions}

3.1 Difference in Learning Outcomes for Students Who Learn Using Problem-Based Learning Models than Those Who Learn Using Direct Learning Models

The analysis of covariance presented in Table 1 shows the existence of significant differences between experimental and control groups in the cognitive domain $(\mathrm{F}(3.11)=27.38, \mathrm{p}<0.05)$, affective domain $(\mathrm{F}$ $(3.11)=35.01, \mathrm{p}<0.05)$, and psychomotor domain $(\mathrm{F}(3.11)=24.21, \mathrm{p}<0.05)$.

Results indicated that the experimental group's mean score taught using problem-based learning models was higher than the mean score of the control group on the learning outcomes (cognitive, affective, and psychomotor domain). As it was seen from Table 2, there was a reasonable difference between the experimental and control groups.

Generally, this study shows that the problem-based learning model is beneficial for brake systems' basic competency. In the matter of basic competency of brake systems, students face problems in the world of work, for example, maintenance and repair of brake system components. The problem-based learning model is a learning model that orientates students to problems, teaches students to be independent in finding problem solutions, and develops students' abilities in analyzing the issues they faced (Widiada et al., 2013).

Problem-based learning can improve students in finding problem-solving solutions because more questions can be analyzed by students when the practicum for the basic competency subject. Students actively discussed solving the teacher's problems with the topics and were encouraged to solve the problem using analytical thinking and encourage to apply their knowledge (Anazifa, 2016). Students are also encouraged to seek and gather information about the problem they will crack, analyze, and associate the relationship between information relating to the issues (Argaw et al., 2017). All those activities also increase students' understanding of issues that influence student achievement, especially cognitive aspects (Anazifa, 2016). So it can be concluded that problem-based learning models has a positive impact on improving not only student cognitive learning outcomes, but also affective and psychomotor learning outcomes. This study's results are in line with research (Qomariyah, 2019), which concludes that there are differences in learning outcomes between groups of students taught with the PBL model compared to groups of students taught with conventional models. Arends (2012) states that the problem-based learning model is a suitable model to be used in developing students' higher-order thinking skills.

The study of Vesife \& Guler (2008) revealed that students found the problem-based learning method's efficiency and increased their learning motivation. According to students, the problem-based learning method is a fun group-based method that takes real-life examples, encourages students to do research, provides permanent knowledge, and increases interest in lessons. In line with the opinion of Sanjaya (2007) that the advantages of problem-based learning are (1) good learning strategies; (2) increase student motivation; (3) stimulating students' ability to find new knowledge; (4) assisting students in applying problems in everyday life; (5) improve critical thinking skills; (6) train students' responsibility attitude; and (7) it makes it easier for students to understand concepts to solve problems in real life. These advantages make students who are taught using problem-based learning models also have a higher level of creativity than students who are taught using direct learning models (Dasining, Muslim, \& Handajani, 2019).

Table 1. ANCOVA Results for Learning Outcomes in Three Domains (Cognitive, Affective, Psychomotor)

\begin{tabular}{llllll}
\hline \multicolumn{1}{c}{ Source } & & $\mathrm{df}$ & Mean Square & $\mathrm{F}$ & Sig \\
\hline Cognitive domain & 1 & 745.47 & 27.38 & 0.00 \\
Affective domain & 1 & 874.49 & 35.01 & 0.00 \\
Psychomotor domain & 1 & 521.11 & 24.21 & 0.00 \\
\hline
\end{tabular}

Table 2. Learning Outcomes of Students Who Learn by Using Problem-Based Learning and Direct Learning Models

\begin{tabular}{|c|c|c|c|c|c|}
\hline \multirow{2}{*}{ Domain } & \multirow{2}{*}{ Learning Models } & \multirow{2}{*}{ Mean } & \multirow{2}{*}{ Std. Error } & \multicolumn{2}{|c|}{ 95\% Confidence Interval } \\
\hline & & & & Lower Bound & Upper Bound \\
\hline \multirow{2}{*}{ Cognitive } & Problem-based learning & 79.52 & 0.89 & 77.74 & 81.31 \\
\hline & Direct learning & 73.00 & 0.87 & 71.26 & 74.73 \\
\hline \multirow{2}{*}{ Affective } & Problem-based learning & 80.29 & 0.85 & 78.58 & 82.00 \\
\hline & Direct learning & 73.22 & 0.83 & 71.55 & 74.88 \\
\hline \multirow{2}{*}{ Psychomotor } & Problem-based learning & 80.26 & 0.79 & 78.67 & 81.85 \\
\hline & Direct learning & 74.80 & 0.77 & 73.26 & 76.34 \\
\hline
\end{tabular}




\subsection{Learning Outcomes for Students Who Have A High Level of Analytical Skills Compared to Learning} Outcomes for Students with A Low Level of Analytical Skills

The analysis of covariance presented in Table 3 shows the existence of significant differences between students who have high analytical skills and students who have low analytical skills in the cognitive domain $(\mathrm{F}(3.11)=9.32, \mathrm{p}<0.05)$, affective domain $(\mathrm{F}(3.11)=11.42, \mathrm{p}<0.05)$, and psychomotor domain $(\mathrm{F}(3.11)=5.27$, $\mathrm{p}<0.05)$.

The results showed that the average score of students who had high analytical skills was higher than those who had low analytical skills on learning outcomes (cognitive, affective, and psychomotor domains). As shown in Table 4, there is a reasonable difference between students who have high analytical skills and low analytical skills.

Students who have high analytical skills in problem-based learning models tend to get higher learning outcomes than students who use direct learning models (Qomariyah, 2019), even though their level of analytical skills is the same high. It is because the problem-based learning model fits the characteristics of students who have high analytical skills. After all, students who have high analytical skills enjoy analyzing and looking for logical and reasoned problem solutions. Besides, students who have high analytical skills by being taught using problem-based learning models are more active in conveying ideas or solving problems than students who are taught using direct learning models. Students who have high analytical skills are less able to develop higher-order thinking if they are only fixated on the teacher's information. The acquisition of high learning outcomes impacts cognitive assessment and has a positive effect on students' affective and psychomotor reviews.

So, it can be concluded that the learning outcomes of students who have high analytical skills are significantly higher than the learning outcomes of students who have low analytical skills in the basic competency subjects of the brake system in SMKN 2 Kupang. This study's results are in line with Parjono (2009), which found that problem-solving-based learning can improve students' high-level cognitive abilities in the form of analytical, synthesis, and evaluation skills. Problem based learning can improve students' cognitive skills if the primary material has been mastered, carried out in small groups with group members with the same abilities, and intensive guidance by the teacher. Suherman \& Sukjaya (1990) state that analytical skills can detail or describe a problem into smaller parts and understand the relationship between these parts. Students trained in analytical thinking skills are very beneficial for their academic achievement (Montaku, Kaittikomol, \& Tiranathanakul, 2012).

Table 3. ANCOVA Results for Learning Outcomes of Students with High and Low Level of Analyticall Skills

\begin{tabular}{ccccc}
\hline Source & df & Mean Square & F & Sig \\
\hline Cognitive domain & 1 & 253.88 & 9.32 & 0.00 \\
Affective domain & 1 & 285.28 & 11.42 & 0.00 \\
Psychomotor domain & 1 & 113.46 & 5.27 & 0.02 \\
\hline
\end{tabular}

Table 4. Learning Outcomes of Student with High and Low Analytical Skills

\begin{tabular}{cccccc}
\hline \multirow{2}{*}{ Domain } & Analytical Skill Level & \multirow{2}{*}{ Mean } & Std. Error & \multicolumn{2}{c}{$95 \%$ Confidence Interval } \\
\cline { 5 - 6 } Cognitive & High & 78.17 & 0.88 & 76.40 & Lower Bound \\
& Low & 74.35 & 0.88 & 72.59 & 79.93 \\
\multirow{2}{*}{ Affective } & High & 78.77 & 0.84 & 77.09 & 80.12 \\
& Low & 74.73 & 0.84 & 73.05 & 76.46 \\
\multirow{2}{*}{ Psychomotor } & High & 78.80 & 0.78 & 77.24 & 80.37 \\
& Low & 76.26 & 0.78 & 74.69 & 77.82 \\
\hline
\end{tabular}

\subsection{The Interaction Between Problem-Based Learning Models and Level of Analytical Skills toward Learning Outcomes}

The covariance analysis presented in Table 5 shows an interaction between problem-based learning models and direct learning models with students' analytical abilities on learning outcomes in the cognitive domain $(\mathrm{F}(3.11)=18.49, \mathrm{p}<0.05)$, affective domain $(\mathrm{F}(3.11)=11.42, \mathrm{p}<0.05)$, and psychomotor domain $(\mathrm{F}(3.11)=5.27$, $\mathrm{p}<0.05)$. The results showed that students who have high analytical skills taught with problem-based learning models have a higher average score of learning outcomes than students who have high analytical skills taught by using direct learning models. As shown in Table 6, there are reasonable differences between students taught with a problem-based learning model and a direct learning model. From the hypothesis testing, it can be concluded that there is an interaction between the use of problem-based learning models 
and direct learning models on learning outcomes (cognitive, affective, and psychomotor domains) in the basic competency subject of the brake system at SMKN 2 Kupang. This study's results are in line with the research of Ahmet \& Geyik (2008), which shows that the application of the problem-based learning model affects students' analytical thinking skills. The problem-based learning model is more effective in improving student learning outcomes (Ulger, 2018). While direct learning models are more effective at improving learning outcomes for students with low analytical skills (Widiada et al., 2013). The problem-based learning model is more active and interactive, making students who have high analytical skills more pro-active and easy to understand the subject matter (Sari et al., 2019).

For students with high analytical skills, the direct learning model is monotonous, less attractive, and information tends to be teacher-centered. Students who have high analytical skills tend to be passive and less able to understand the subject matter taught by direct learning models (Qomariyah, 2019). While problem-based learning models are less useful for students with low analytical skills because they have an active learning concept. Students who have low analytical skills will have difficulty understanding the subject matter (Widiada et al., 2013). Meanwhile, the direct learning model is more effective for students with low analytical skills because the direct learning model provides coherent material and information that tends to be teacher-centered. Students with low analytical skills will find it easier to understand the subject matter. The interaction between learning models and students 'analytical skills in learning outcomes illustrates the relationship between learning models and students' analytical skills as factors that influence learning outcomes. From the research results, it can be seen that the use of problem-based learning models is more effective than the use of direct learning models for groups with high analytical skills. Meanwhile, direct learning models are more effective than using problem-based learning models for groups with low analytical skills (Birgili, 2015).

Table 5. ANCOVA Results for Learning Outcomes of Students Who Learn by Using Problem-Based Learning and Direct Learning

\begin{tabular}{ccccc}
\multicolumn{5}{c}{ Models } \\
\hline Source & df & Mean Square & F & Sig \\
\hline Cognitive domain & 1 & 503.48 & 18.49 & 0.00 \\
Affective domain & 1 & 504.71 & 20.20 & 0.00 \\
Psychomotor domain & 1 & 465.29 & 21.26 & 0.00 \\
\hline
\end{tabular}

Table 6. Learning Outcomes of Students Who Learn by Using Problem-Based Learning and Direct Learning Models

\begin{tabular}{|c|c|c|c|c|c|c|}
\hline \multirow{2}{*}{ Domain } & \multirow{2}{*}{ Learning Models } & \multirow{2}{*}{ Student Analysis Skills } & \multirow{2}{*}{ Mean } & \multirow{2}{*}{ Std. Error } & \multicolumn{2}{|c|}{ 95\% Confidence Interval } \\
\hline & & & & & Lower Bound & Upper Bound \\
\hline \multirow{4}{*}{ Cognitive } & Problem-based & High & 84.118 & 1.266 & 81.591 & 86.644 \\
\hline & learning & Low & 74.941 & 1.266 & 72.414 & 77.468 \\
\hline & \multirow{2}{*}{ Direct learning } & High & 72.222 & 1.230 & 69.767 & 74.678 \\
\hline & & Low & 73.778 & 1.230 & 71.322 & 76.233 \\
\hline \multirow{4}{*}{ Affective } & Problem-based & High & 85.000 & 1.210 & 82.580 & 87.420 \\
\hline & learning & Low & 75.580 & 1.210 & 73.160 & 78.000 \\
\hline & \multirow{2}{*}{ Direct learning } & High & 72.550 & 1.170 & 70.200 & 74.900 \\
\hline & & Low & 73.880 & 1.170 & 71.530 & 76.240 \\
\hline \multirow{4}{*}{ Psychomotor } & Problem-based & High & 84.118 & 1.125 & 81.871 & 86.364 \\
\hline & learning & Low & 76.412 & 1.125 & 74.166 & 78.658 \\
\hline & \multirow{2}{*}{ Direct learning } & High & 73.500 & 1.093 & 71.317 & 75.683 \\
\hline & & Low & 76.111 & 1.093 & 73.928 & 78.294 \\
\hline
\end{tabular}

\section{Conclusions}

Based on the results of data that student learning outcomes using problem-based learning models are significantly higher than learning outcomes for students who use the direct learning models in the basic competency subjects of the brake system in SMKN 2 Kupang. The learning outcomes of students who have high analytical skills are significantly higher than the learning outcomes of students who have low analytical skills in the basic competency subjects of the brake system in SMKN 2 Kupang. There is an interaction between the use of problem-based learning models and direct learning models on learning outcomes (cognitive, affective, and psychomotor domains) in the basic competency subject of the brake system at SMKN 2 Kupang. 


\section{Acknowledgement}

The authors would like to thanks the supervisors from State University of Surabaya for their assistance in the completed this study.

\section{Author's Contributions}

All authors discussed the results and contributed to from the start to final manuscript.

\section{Conflict of Interest}

The authors declare that they have no competing interests.

\section{References}

Ahmet, G., \& Geyik, E. (2008). Teaching of the concept of enthalpy using problem based learning approach. Turkey: Department of Science Education.

Anazifa, R. D. (2016). The Effect of problem- based learning on critical thinking skills and student achievement. In Proceeding of 3rd International Conference on Research, Implementation and Education of Mathematics and Science (pp. 43-48).

Aprilianu, D., Rijanto, T., Ismawati, R., \& Wiyanto, T. (2020). The Effect of Problem-Based Learning Model of Food Cutting Competency Toward the Student Learning Outcomes of Class X at SMK YPM 2 Taman. International Journal for Educational and Vocational Studies, 2(3).

Argaw, A. S., Haile, B. B., Ayalew, B. T., \& Kuma, S. G. (2017). The effect of problem based learning (pbl) instruction on students' motivation and problem solving skills of physics. EURASIA Journal of Mathematics Science and Technology Education, 13(3), 857-871. https://doi.org/ 10.12973/eurasia.2017.00647a

Birgili, B. (2015). Creative and critical thinking skills in problem-based learning environments. Journal of Gifted Education and Creativity, 2(2), 71-71. https:/ / doi.org/10.18200/jgedc.2015214253

Dasining, Muslim, S., \& Handajani, S. (2019). The effect of problem based learning and levels of creativity toward student outcomes in vocational high school. International Journal for Educational and Vocational Studies, 1307(1), 595-598. https:/ / doi.org/10.1088/ 1742-6596/1307/1/012010

Dewi, A. K. (2019). Improving students learning outcomes through mind map in human reproductive system topic in natural science learning. International Journal for Educational and Vocational Studies, 1(7), 702-706.

Kharismaputra, A. P., Santoso, S., \& Murwaningsih, T. (2020). Improving Critical Thinking Skills of Vocational School Students Using Problem-Based Learning. International Journal for Educational and Vocational Studies, 2(5).

Montaku, S., Kaittikomol, P., \& Tiranathanakul, P. (2012). The model of analytical thinking skill training process. Research Journal of Applied Sciences, 7(1), 17-20. https:/ / doi.org/10.3923/rjasci.2012.17.20

Mustofa, R. F., Corebima, A. D., Suarsini, E., \& Saptasari, M. (2019). The Problem-Based Learning Model and Students' Generic Skills of the Faculty of Teachers Training and Education the Universitas Siliwangi Tasikmalaya on the Animal Structure Course. International Journal for Educational and Vocational Studies, 1(1), 53-57.

Parjono, W. (2009). Peningkatkan kemampuan analisis, sintesis, dan evaluasi melalui pembelajaran problem solving. Universitas Negeri Yogyakarta.

Puspitasari, R., Miarsyah, M., \& Rusdi, R. (2020). Flash Based Interactive Multimedia Development to Increasing Learning Outcomes of Participants in High School in Materials Excretory System. International Journal for Educational and Vocational Studies, 2(4).

Qomariyah, S. N. (2019). Effect of problem based learning learning model to improve student learning outcomes. International Journal of Educational Research Review, (2009), 217-222. https://doi.org/10. 24331/ijere.518056

Sanjaya, W. (2007). Strategi pembelajaran berorientasi standar. Jakarta: Kencana Prenanda Media.

Sari, R., Perdana, R., Riwayani, Jumadi, Wilujeng, I., \& Kuswanto, H. (2019). The implementation of problem-based learning model with online simulation to enhance the student's analytical thinking 
skill in learning physics. Journal of Physics: Conference Series, 1233(1). https://doi.org/10.1088/17426596/1233/1/012030

Siregar, A., Nurlela, L., Marniati, M., Rijanto, T., \& Munoto, M. (2020). The Application of Problem-Based Learning Method for Hygiene Sanitation Learning Eyes. International Journal for Educational and Vocational Studies, 2(2).

Setyosari, P. (2010). Metode penelitian dan pengembangan. Jakarta: Kencana Prenanda Media.

Sugiyono. (2013). Metodologi penelitian kuantitatif kualitatif R\&D. Bandung: Alphabeta.

Suherman, \& Sukjaya. (1990). Petunjuk evaluasi untuk melaksanakan evaluasi pendidikan matematika. Bandung: Wijayakusuma.

Susanto, A. (2012). Teori belajar dan pembelajaran di sekolah dasar. Jakarta: Prenada Media Grup.

Ulger, K. (2018). The effect of problem-based learning on the creative thinking and critical thinking disposition of students in visual arts education. Interdisciplinary Journal of Problem-Based Learning, 12(1), 3-6. https://doi.org/10.7771/1541-5015.1649

Vesife, \& Guler, A. (2008). Student views on problem-based learning of 9th grade industrial vocational high school. Ankara: Dikmen Industrial Vocational High school.

Wahyuni, D., Samani, M., Wiyanto, T., \& Rijanto, T. (2020). Influences of Problem-Based Learning Models on Class XI Students Learning Outcomes in Subject of Light Vehicle Engine Maintenance at KAL-1 Vocational School Surabaya. International Journal for Educational and Vocational Studies, 2(5).

Ward, J., \& Peppard, J. (2002). Strategic planning for information system (Third Edition). Bedfordshire: John Willey \& Sons.

Widiada, I. P. G., Candiasa, M., \& Natajaya, N. (2013). Pengaruh implementasi model pembelajaran berbasis masalah terhadap hasil belajar matematika ditinjau dari kecerdasan logis matematis pada siswa kelas X Akomodasi Perhotelan SMK PGRI Payangan. E-Journal Program Pascasarjana Universitas Pendidikan Ganesha, 4, 1-11.

Widiantoro, O., Kusnan, K., Suparji, S., \& Rijanto, T. (2020). Differences in Learning Outcomes Using Direct Learning Models Viewed from Spatial Ability: Study At Basic Survey Working Lesson in the Engineering Surveying. International Journal for Educational and Vocational Studies, 2(4). 